\title{
Digital Marketing Perspective in Cattle Business: Supply Chain Integrated Approach.
}

\author{
Ahmad Shabudin Ariffin, ${ }^{1 *}$ Mona Fairuz Ramli, ${ }^{1}$ and Hasbullah Ashari ${ }^{2}$ \\ ${ }^{1}$ Faculty of Business and Science Management, Kolej universiti Islam Perlis, Kuala Perlis, Malaysia \\ ${ }^{2}$ Department of Management and Humanities, Universiti Teknologi PETRONAS, Seri Iskandar, Perak
}

\begin{abstract}
The Malaysian economy has experienced robust economic growth over the past few decades, averaging around 6 per cent a year since 2000. With competitive pressure for resources from non-agriculture sectors, there is likely to be an inadequate capacity to increase agricultural production. Attaining agriculture business performance continued relevance remains demanding in the Eleventh Malaysia Plan. Anchored in the supply chain management philosophy, this paper highlights cattle businesses and the interrelated elements of supply chain integration and a digital marketing perspective. The cattle meat industry in Malaysia is gradually transforming from unorganized backyard farming into organized farming. However, the supply chains are still characterized by inefficiencies, diseconomies of scale, lack of investments, and inadequate arrangement. Therefore, to improve the efficiency and economy of scale, added value chain is required. One form of value creation is technology adoption. The digital marketing part of technology currently leads to the adoption new business policies in agriculture production. Policies and procedures also need to be eased to facilitate investments to increase production. This paper concludes that, in many important ways, the Malaysian Government still sees food security as a public obligation, especially in the case of protein-based products, and is working attentively to increase food security for its citizens.
\end{abstract}

Keywords - Supply chain integration, food security, cattle industry formatting

\section{INTRODUCTION}

Agriculture production is common in many developing nations, where a considerable percentage of the population participates. Nevertheless, for a variety of reasons, the number of Malaysians involved in agriculture is steadily declining. First, rapid development pushes rural residents towards cities in search of better employment opportunities. As a result, finding people to manage farms becomes increasingly challenging. Second, development impacts the amount of arable land accessible for farming. More and more buildings and factories are being constructed, hence arable land continues to shrink over time. Finally, compared to Malaysia's thriving pig and poultry industries, livestock production is a dying business. In the ruminant industry, escalating productivity is a major problem, as it struggles with the efficient use of natural resources and adoption of integrated supply chain solutions for livestock production.

Livestock is a substantial component of Malaysia's agricultural industry and contributes significantly to Gross Domestic Product, accounting for around $15.5 \%$ in 2020 [1]. According to the World Data Atlas, it generated 107.4 index for food production and $8.21 \%$ for the country's agriculture in 2020 [1]. Peninsular Malaysia is mostly known for its animal farming industries. The poultry and pig industries are the most established and significant sectors, accounting for the majority of overall livestock output. Ruminant producers are battling to boost their output. Most significantly, their population continues to decline. In general, Malaysia's farming system is smallholder, with low input and output. Malaysia began importing breeding cattle in large quantities to raise the base population with the goal of achieving self-sufficiency in animal products. Beef production has been promoted through the use of integrators and effective contract farming. The system's potential has been demonstrated in the poultry sector, and the concept is convincing given Malaysia's extensive use of contract growers. Numerous countries in the tropics are gradually adopting European ruminant breeds in an effort to boost production. Malaysia has also embarked on an importation effort with numerous cattle breeds, seeking to identify the most adaptable breeds to the environment. The dairy breeds introduced in the late 1970's and early 1980's included Holstein-Friesian, Australian Milking Zebu, Brown Swiss, Ayreshire, Jersey, and Shorthorn [2].

\footnotetext{
* Corresponding Author: shabudin@kuips.edu.my
} 
In relation to the livestock industry, the animal feed industry is also critical to national security. The animal feed industry faces a variety of obstacles including price unpredictability, intrinsic commercial and climate risks associated with its many subsectors, and a variety of other obstacles. They have significant effects on the stakeholders in the entire supply chain. They must contend with the price reduction efforts from the buyers. This is since the feed sector is an important component in the value chain that will determine the cost of the livestock in general.

Producers also face numerous problems in the fast and risky climate. The farmers have to increase their efficiency and effectiveness in order to farm sustainably. Significant entry obstacles exist across the value chain. They include the need for high capital, years in business, seed production technology and capability, enough volume in major inputs such as fertilizer and other operational and logistical factors. Such entrance obstacles make it difficult for newcomers and smaller firms to compete with established competitors in the industry. Meanwhile, customised technology in this chain would ensure seamless operation [32], [33]. For instance, e-procurement farm producers might be selected via the internet due to the data's ability to give the necessary information to the existing and potential consumer [35].

For the last three decades, livestock production has grown at a breakneck pace. According to Delgado et al. (1999), economists agree that increased demand was a factor in cattle output development, which was fueled by growing populations and per capita incomes. Contractually, the relationship between enterprises and farmers within the economic boundaries has exploded in the previous two decades. According to [3], [4], and [5], contract farming studies in Asia and Africa have revealed an increase in this phenomenon, albeit at a slower pace than in Latin America. According to [6], contract relationships have developed subtly to the extent that they have expanded the global system - for example, between input suppliers in New Zealand and pumpkin producers in Tonga, as well as between purchasers and consumers of the finished product in Kobe, Japan. The evolution of food and agricultural markets has contributed to the requirement for increased degrees of regulated coordination in agriculture commodity value chains. "As a result, various forms of vertical integration and alliances have developed into a prominent element of agricultural supply chains [7]." Due to these changes, customer demand for unique agricultural goods has increased globally [8]. The demands together with their worries about food safety, have created significant challenges for developing countries. The food and agricultural produce which include fresh fish, meat, and vegetable make up more than fifty percent of the countries food and agricultural exports [9].

Agricultural production used to be a small-scale, unorganised business in many developed countries, but the industry has evolved dramatically in recent years as larger enterprises have closely integrated across the manufacturing and distribution value chains [10]. The market-oriented reforms in the aftermath of international trade liberalisation, particularly in developing countries' structural adjustment plans, has resulted in growing global market integration [11]. Contract farming has played a part in bridging the divide between farmers and huge corporations. It is a method based on "contractual arrangements between farmers and companies, whether oral or written, outlining one or more production and/or marketing criteria for an agricultural product [12]." Contract farming has various forms depending on the production and/or marketing parameters specified. There are continuous debates surrounding the pro and cons of the contract farming since the 1970s [13], [14], [15]. Opponents of contract farming believe that huge agribusinesses utilise contracts to exploit inexpensive labour and shift production risk to farmers. Another issue is that the small farmers will be sidelined since firms choose to work with more well- to- do farmers [5], [16]. Others are more optimistic, viewing contract farming as a way to connect the small farmers with the market and the contract farming also ensure the small farmers to have a consistent technical assistance, continuous supply of quality seeds and fertilizer, and a stable price of the produce.

\section{DIGITAL MARKETING}

In the last few years, digital marketing, in parallel with IR 4.0, has increasingly played a dynamic role in supply chain management [36], [37]. Technology like digital marketing improves supply chain communication and offers move efficiently integrative supply chain move efficiently [29]. A digital marketing strategy is a value creation and value capture point in a supply chain, especially in contract farming and manufacturing sectors [30]. In a digital marketing mode, a food producer increases customer demand by realizing a supplier's ability to provide the raw material that required based on livestock farming readiness [31].

To increase efficiency, vertically integrated systems in the livestock and commodities supply chains use digital marketing, which enables consumers and suppliers to evaluate the price, location, promotion, and product base at their leisure [34], [37]. These initiatives are typically focused on providing accurate price information, disseminating fanning expertise, eliminating intermediaries, and transforming agricultural supply chains that support the livelihoods of billions of people worldwide [31], [34]. Agriculture is a rapidly growing business in many developed countries, contributing a significant portion of economic growth in lockstep with technological advancements [36]. The digital marketing component of technology has offered an 
enormous possibility for farms to exchange information across numerous chains, making it easier for businesses to manage material flow across multiple suppliers and retailers [27], [34].

\section{METHODS}

This project employed a digital marketing and food supply chain strategy, acquiring and analysing data on the cattle supply chain. Traditionally, the supply chain entails the flow of resources downstream and information upwards. Torres [17] defines supply chains as "a system comprised of material suppliers, manufacturing facilities, distribution services, and customers that are connected by the feedforward flow of materials and feedback of information." The food supply chain is viewed as a series of steps that constitute a particular sequence of economic activities through which resources and materials flow downstream for the manufacturing of commodities and provision of services destined for ultimate consumer consumption, as well as information feedback. Additionally, the food supply chain is viewed as a network of organisations with economic ties to one another that enables the supply chain to function and provide commodities and services. A critical aspect of any system-based assessment is a well-defined system boundary [18]. The following stages comprise the food supply chain: raw material extraction, agricultural production, primary processing, secondary processing, final manufacture, wholesale, retail, food service, and domestic consumption. The study is focused on Kumpulan Ladang Kedah Sdn Bhd and its subsidiary, KLPK Sdn Bhd.

\section{RESULTS AND DISCUSSION}

The literature review revealed certain critical variables that should be included in the study. KLPK Sdn Bhd believes there is a need to continue scientific research into the cattle business using the integrated supply chain model. Additionally, the requirement to adapt to technological advancements in IR 4.0, such as interactive digital marketing, peer-to-peer networks, data science, and IoT, will alter industry scenarios in numerous ways by disrupting company models [29], [37]. SCM is seen as a management philosophy by some scholars, a management process by others, and an integrated system by others. However, Heller and Keoleian [19] defined supply chain management as the movement of materials and products, while Tyndall, Gene, Gopal, Partsch, et al. [20] defined supply chain management as a network of organisations involved in the various processes and activities that generate value in the form of products and services that end up in the hands of the ultimate customer via upstream and downstream linkages. Thus, in the livestock industry, the supply chain can be defined as the process of integrating suppliers and customers, beginning with raw materials (such as agricultural inputs) and ending with the consumption of finished goods.

The term "integrating suppliers" refers to a business's collaboration with suppliers and its perception that the suppliers are important for the company survival [21]. This study evaluated the extent to which suppliers are involved and influence company decisions. Additionally, it assessed how closely suppliers collaborate with the company to finalise a contract [22]. Strategic collaboration with suppliers may relate to more intimate, long-term ties [23]. Previous research has also looked at the effect of supplier involvement effort on performance [24]. [25] reports on one of the early examinations of the influence of supplier involvement effort. In general, this study emphasises the beneficial aspects of supplier involvement in the livestock industry. Perhaps this outcome is predicted in the landscape of cattle contract farming.

Meanwhile, the term "integrating customers" refers to a business's tight relationship with its customers and its perception of the latter as an important key player in the chain [21]. This adaptive term is also used in this article to refer to the degree of client involvement and influence over a business's choice. Furthermore, it will increase the degree to which clients collaborate with the organisation to complete the business transaction [26]. An effective and efficient integration with the customers help the company to better understand the customers' needs and wants [15] which eventually lead to a better product quality and ability to fulfill the demand.

The grow in customers' demand couples with increase in complexity of their requirements have affected agriculture prices and the technology requirements. This phenomenon is also the impetus for the development of the integrated global food and agricultural systems. The integration creates new chances for suppliers, consumers, producers, researchers, and entrepreneurs to share commodities, services, and ideas. Advancements in technology and other disciplines have complemented these changes, leading to the potential to significantly alter the magnitude and quality of food and agricultural products. These fast developments force the developing nations' agricultural sectors to respond quickly to benefit from the evolving global system. The constant innovation will be the norm, and developing countries' policies, programs, and investments will need to be innovative to keep up.

Beef is a significant protein source in the Malaysian diet. National beef consumption is predicted to increase as disposable personal income and population growth rise. However, the domestic beef sector is underdeveloped and does not reflect the magnitude of domestic demand. Domestic beef production via cattle-oil-palm integration has the potential to be a profitable endeavour, particularly in light of current economic difficulties. Land is a significant cost item in beef production; however, this can be reduced if output is shared with other firms. Cattle rearing under oil palm trees is an excellent choice. This will boost 
land-use intensity while decreasing the cost of oil-palm upkeep. Under this integrated agricultural approach, both enterprises, namely oil palm and cattle, will generate greater overall returns per hectare of land exploited. Previous research has demonstrated a highly convincing outcome. Cost-benefit analysis (CBA) was used to determine the financial costs and rewards associated with integrated cow husbandry beneath oil palm trees. Several indicators of project value, including net present value (NPV), internal rate of return (IRR), and benefit-cost ratio (B-C ratio), were calculated using data from three case studies. Sensitivity tests of the IRR and B-C ratios at various beef prices were conducted to demonstrate the project's resilience to changes in critical market parameters. The NPV calculation subtracts the discounted future cash inflow from the discounted present cash outflow, with positive numbers indicating a project's viability. Among alternative initiatives, those with a greater net present value (NPV) are preferred. The IRR is the discount rate at which the net cash flow becomes zero. When the IRR exceeds the opportunity cost of funding, the project is financially viable. The B-C ratio compares the discounted cash inflow to outflow, and a B-C ratio greater than unity indicates a sound project.

KLPK Sdn Bhd will explore this type of farming system and prepare for a justifiable production system through an understanding of the interconnections between the system's primary components. The investigation should take a systemic perspective in order to comprehend the dynamics of the entire system scenario. We anticipate that integrated production systems will contribute to economic, socioeconomic, and ecological development in the future. Effective logistics entail delivering the correct product, in the correct quantity, in the correct condition, at the correct location, at the correct time, and at the correct cost, all of which promote the success of supply chain participants. Previously, experts described the development in the food value chain as being characterised by three overarching aspects, including a growing concentration of farms, food companies, and wholesalers into a small number with a huge size. The evolution of integrated supply chains, which connect producers and other stakeholders, is the second. Thirdly, customer demand for food quality, food safety, and animal welfare is increasing. However, the connection between the logistics systems of cattle industry stakeholders and food supply chains is still quite loose and fragmented. Even within individual enterprises, vertical and internal integration in freight and logistics are lax, and, as a result, they are inefficient and unsustainable on both an economic and environmental level. Effective and efficient logistics will be vital to the success of both manufacturers and retailers in this area.

An integrated supply chain approached as discussed above is imperative in improving the current fragmented and inefficient local food supply chain. It will integrate the key players in the supply chain such as the farmers, slaughtering house, processors, distributors, and users in a more coordinated and sustainable way. In addition, the digitalization will improve the tracking of the animals from birth to final products. These improvements are imperative for a sustainable livestock industry that will improve the food security issues faced by this country.

\section{CONCLUSION}

Kumpulan Ladang Kedah Sdn Bhd, through its subsidiary KLPK Sdn Bhd, would enter the cattle farming business using an integrated supply chain approach. By cultivating animal products within identity-protected supply chains, producers can increase the value of their products. This may broaden producers' options if a variety of rival supply chains prove more adept at securing future contracts. Additionally, as technology advances, farm producers must be prepared to transition from old to modern business models that use technology more effectively. In this scenario, adaptable digital marketing in the supply chain management process is a priority.

Implications of the revolution digitalization in supply chain management process will abound for the types of production, marketing, and relationship risks that producers face. This, however, could be true of any new enterprise on the farm and has little to do with enhanced vertical coordination. Changes to the digital marketing or input supply connection will necessitate the acquisition of new contract evaluation and negotiating abilities. Producers will need to take a more proactive approach to digital marketing. It is hoped that examining all of the aspects described above will assist in alleviating investors' concerns about combining cattle breeding businesses with feedlot and breeding farm operations concurrently. KLPK Sdn Bhd plans to continue conducting scientific research in partnership with the university as part of its attempt to ascertain the present and future direction of the company.

\section{REFERENCES}

[1]. Department of Verterinar Malaysia, "Malaysia: Livestock population 2017-2018," 2018.

[2]. M. Murugaiyah, "Reproductive performances of imported Jersey cows in Malaysia," MSc Thesis, Universiti Putra Malaysia, 1982.

[3] H. Barrett, B. Ilbery, A. Browne, and T. Binns, "Globalisation and the changing networks of food supply: the importation of fresh horticultural produce from Kenya into the UK," Trans. of the Inst. of British Geographers, 24, pp. 159-174, 1999. 
[4] D. Glover and L. Teck Ghee, Contract Farming in Southeast Asia: Three Country Ttudies, Kuala Lumpur: Institute for Advanced Studies: Universiti Malaya, 1992.

[5] P. Little and M. Watts, Eds. Living Under Contract: Contract Farming and Agrarian Fransformation in Sub-Saharan Africa. Madison, Wisconsin: University of Wisconsin Press, 1994.

[6] W. E. Murray, "From dependency to reform and back again: The Chilean peasantry in the twentieth century," J. of Peasant Studies, 29(3-4), pp. 190-227, 2002.

[7] J. Kirsten and K. Sartorius, "Linking Agribusiness and small-scale farmers in Developing Countries: Is there a new role for Contract Farming?” Dev. Southern Africa, 19(4), pp.503-529, 2002.

[8] V. J. Rhodes, Industrialization of agriculture: discussion. Am. J. of Ag. Econ., 75(5), pp. 1137-1140, 1993.

[9] L. J. Unneveher," Food safety issues and fresh food product exports from LDCs.” Ag. Econ., 23, pp. 231-240, 2000.

[10] M. Boehlje, "Critical dimensions of structural change. Unpublished document, Department of Agricultural Economics. West Layafette: Purdue University, 2000.

[11]. T. Reardon and C. B. Barrett, "Agroindustrialization, globalization and international development: An overview of issues, patterns and determinants," Ag. Econ. (Special Issue), 23, pp. 195-205, 2000.

[12] P. R. Ewell, Contract Farming, U.S.A. Danville, Ill.: The Interstate, 1963.

[13]. J. D. Morrisey, Agricultural Modernization Through Production Contracting: The Role of the Fruit and Vegetable Processor in Mexico and Central America. Praeger, New York, 1974.

[14] D. Glover, "Contract farming and smallholder outgrower schemes in less-developed countries," World Dev., 12(11/12), pp. 1143-1157, 1984.

[15] N. Minot, "Contract farming and its effect on small farmers in less developed countries," MSU International Development Papers, Working Paper No. 31. Department of Agricultural Economics. East Lansing, MI: Michigan State University, 1986.

[16] S. Singh, "Contracting out solutions: Political economy of contract farming in the Indian punjab," World Dev. 30(9), pp. $1621-1638,2002$.

[17] G. Torres, The Force of Irony: Power in the Everyday Life of Mexican Tomato Workers, Oxford: Berg, 1997.

[18] J. Stevens, “Integrating the supply chain,” Int. J. of Phys. Distr. \& Materials Manag., 19(8), pp. 3-8, 1989.

[19] M. C. Heller and G. A. Keoleian, “Assessing the sustainability of the US food system: A life cycle perspective,” Ag. Sys., 76(3), pp. 1007-1041, 2003.

[20] J. Tyndall, G..J, C. Gopal, W. Partsch, and Kamauff.J, Supercharging Supply Chains: New Ways to Increase Value Through Global Operational Excellence. NY: John Wiley \& Sons, 1998.

[21] P. H. U. Jüttner and M. Christopher, "Supply chain risk management outlining an agenda for future research," Int. J. Logist. Manag., 6(4), pp. 197-210, 2003.

[22] W. C. Swink and M. R. Narasimhan, "Managing beyond the factory walls: Effects of four types of strategic integration on manufacturing plant performance," J. Oper. Manag., vol. 25, no. 1, pp. 148-164, 2007.

[23] S. W. Narasimhan and R. Kim, "Effect of supply chain integration on the relation- ship between diversification and performance: evidence from Japanese and Korean firms," J. Oper. Manag., 20(3), pp. 303-323, 2002.

[24] P. Rajagopal, "Supply chain partnering involvement among electrical and electronic firms in Malaysia today," in International Conference Operation Research, Chenai, 2002.

[25] R. B. Handfield, G. L. Ragatz, and K. J. Peterson, "Supplier Integration into New Product Development: Coordinating Product, Process and Supply Chain Design,” J. Oper. Manag., 23, pp. 371-388, 2005.

[26] K. B. Wheelwright, and S. C. Clark, Revolutionizing Product Development: Quantum Leaps in Speed, Efficiency, and Quality, Free Press, 1992.

[27] M. L. Fisher, "What is the right supply chain for your product?," Harv. Bus. Rev., 75(2), pp. 105-116, 1997.

[28] S. Lee, H. L. Padmanabhan, and V. Whang, "The bullwhip effect in supply chains," Sloan Manage. Rev., 38(3), pp. 93$102,1997$.

[29] F. Ciulli, A. Kolk, and S. Boe-Lillegraven, "Circularity brokers: Digital platform organizations and waste recovery in food supply chains, J. of Bus. Ethics, 167(2),pp.299-331,2019, doi: https://doi.org/10.1007/s10551-019-04160-5

[30] S. Menon and S. Shah, "An overview of digitalisation in conventional supply chain management, MATEC Web of Conferences, 292, 01013, 2019, doi: https://doi.org/10.1051/matecconf/201929201013

[31] S. Min, Z. G. Zacharia, and C. D. Smith, "Defining supply chain management: In the past, present, and future,” J. of Bus. Logist., 40(1), pp. 44-55, 2019, doi: https://doi.org/10.1111/jbl.12201

[32] W. Ritz, M. Wolf, and S. McQuitty, "Digital marketing adoption and success for small businesses: The application of the do-it-yourself and technology acceptance models," J. of Res. in Interactive Marketing., 13(2), pp. 179-203, 2019, doi: https://doi.org/10.1108/JRIM-04-2018-0062

[33] GE. ustafsson, P. Jonsson, and J. Holmström, "Digital product fitting in retail supply chains: maturity levels and potential outcomes,” Sup. Chain Manag., 24(5), pp. 574-589, 2019, doi: https://doi.org/10.1108/SCM-07-2018-0247 
[34] K. Gyimesi, and S. Berman, "Digital transformation in the automotive industry. IBM Gobal Bus. Serv., pp. 1-8, Sept. 2019.

[35] N. A. A. Rahman, J. Muda, M. F. Mohammad, M. F. Ahmad, S. A. Rahim, and M. V. Fernando, "Digitalization and leap frogging strategy among the supply chain member: Facing GIG economy and why should logistics players care?" Int. J. of Sup. Chain Manag., 8(2), pp. 1042-1048, 2019.

[36] M. Bakri, "From traditional to digital environment: An analysis of the evolution of business models and new marketing strategies," Manag. Studies and Econ. Sys., 4(3), pp. 225-240, 2019.

[37] V. A. Koshel, T. L. Shklyar, S. A. Avtonomova, and M. G. Shilina, "Generation specific patterns of communication based on the supply chain management in the digital society," Int. J. of Sup. Chain Manag., 8(3), pp. 449-459, 2019.

[38] E. Hofmann, H. Sternberg, H. Chen, A. Pflaum, and G. Prockl, "Supply chain management and Industry 4.0: Conducting research in the digital age," Int. J. of Phys. Dist. and Logist. Manag., 49(10), pp. 945-955, 2019. 